\title{
Comparative Clinical efficacy of Jambu (Eugenia jambolana Lam.) and Kshudra jambu (Syzygium caryophyllatum (L.) Alston.) in Youvana pidaka
}

\author{
Research Article
}

\section{Suma HR ${ }^{*}$, Shrikanth $\mathbf{P}^{2}$, Niveditha Shetty ${ }^{3}$}

1. P.G Scholar, 2. HOD and Professor, 3. Assistant professor, Department of PG studies in Dravyaguna, Sri Dharmasthala Manjuntheshwara College of Ayurveda and Hospital, Kuthpady, Udupi, Karnataka. India.

\begin{abstract}
Aims: To compare the clinical efficacy of mature leaf of Jambu (Eugenia jambolana Lam.) and Kshudra Jambu (Syzygium caryophyllatum (L.) Alston.) in the disease Youvana pidaka (Acne vulgaris like skin manifestation).Introduction: Jambu is said to be two varieties Raja and Kshudra based on overall morphology.These two are said to have same properties, are substituted by each other and their leaf are used for the management of Youvana pidaka in folklore practice.Methods: 30 subjects having signs and symptoms of Youvana pidaka were divided into two groups of 15 each. Group A was administered Jambu patra churna (leaf powder) orally and lepa(face pack) externally once a day and Group B was administered Kshudra Jambu patra churna orally and lepa externally once a day, for a duration of 28 days. Results were assessed using objective parameters like global acne grading scale, extent of lesion, size of pidaka (lesion), healing of pidaka, number of comedones, papule, pustules and nodules, and subjective parameters like itching and srava (discharge) of pidaka. Results were interpreted using suitable statistical tests. Important observation: Jambu and Kshudra Jambu showed highly significant improvement in parameters like GAGS score, number of comedones, size of pidaka, and extent of lesion. Kshudra Jambu was slightly more effective in action than Jambu, but it was statistically insignificant. Results: Jambu and Kshudra Jambu are almost equally effective in the management of Youvana pidaka, but Kshudra Jambu has a slightly higher efficacy.
\end{abstract}

Key Words: Jambu, Kshudra jambu, Syzygium, Youvana pidaka, Acne, Folklore.

\section{Introduction}

A famous poet Kalidasa in his work Mangalastaka quoted the names of 10 trees hoping that the evergreen and ever flowering garden full of fruits yielding trees will be the harbor for the well being of the world. One among these 10 evergreen trees is $J a m b u$ (1). Jambu is one of the keystone species which is well-known for its anti-diabetic potential. Jambu is said to be of different varieties like Raja, maha, Kshudra, Kaka, Jala and Bhumi Jambu (2) Raja means Shresta or superior or having bigger fruit and Kshudra means smaller or inferior or having smaller fruit (3). Both these Jambu bheda is said to have same properties, but Raja Jambu is said to be Shresta(best) among other varieties. (2)

The source of Jambu is Eugenia jambolana Lam., and Syzygium caryophyllatum L.Alston is considered as source of Kshudra Jambu, which is also used as a substitute of Jambu (4). In folklore medicine the mature leaf of Jambu and Kshudra Jambu is used

\section{* Corresponding Author:}

\section{Suma HR}

PG Scholar, Department of PG studies in Dravyaguna,

Sri Dharmasthala Manjuntheshwara College of

Ayurveda and Hospital, Kuthpady,

Udupi, Karnataka. India

Email Id: vaidyasuma@outlook.com externally and orally for the management of pimples. (5) (6)

Pimples or Acne is a very common skin condition mostly occurring in adolescent years, which has a prevalence rate of $76 \%$. (7) This skin condition is self limiting, but if untreated, it leads to permanent scarring of face and impact the psychological wellbeing of an individual. Acne can be correlated to Youvana pidaka in Ayurveda, which is a Kshudra roga (a disease with less dosha vitiation). (8) Since both Jambu bhedha (Jambu varieties) are said to have same properties and are used successfully in the management of Acne, the present research is undertaken to compare their efficacy.

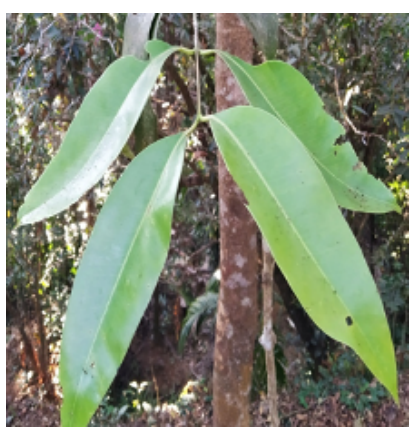

Figure 1: Leaf of Jambu

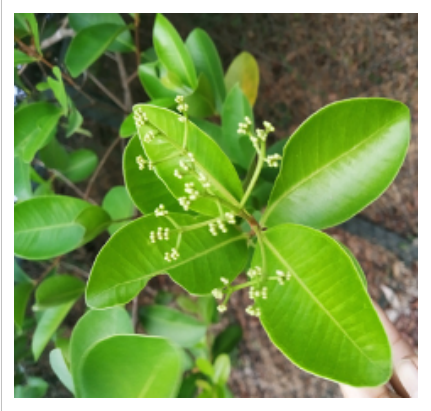

Figure 2: Leaf of Kshudra Jambu 
Table No 1: Brief review of Jambu and Kshudra Jambu (9) (2) (10) (11) (12) (13)

\begin{tabular}{|c|c|c|}
\hline Dravya's & Jambu & Kshudra Jambu \\
\hline $\begin{array}{l}\text { Botanical } \\
\text { name }\end{array}$ & $\begin{array}{l}\text { Eugenia } \\
\text { jambolana Lam }\end{array}$ & $\begin{array}{l}\text { Syzygium } \\
\text { caryophyllatum } \\
\text { L.Alston. }\end{array}$ \\
\hline Family & Myrtaceae & Myrtaceae \\
\hline Synonyms & $\begin{array}{l}\text { Nellanja chada } \\
\text { (bluish green } \\
\text { leaf), Surabhi } \\
\text { (aromatic leaf), } \\
\text { Maha skanda } \\
\text { (large trunk), } \\
\text { Kumarika (fruits } \\
\text { liked by } \\
\text { children), } \\
\text { Jambava(fruit of } \\
\text { Jambu) }\end{array}$ & $\begin{array}{l}\text { Hruswa phala } \\
\text { (smaller size fruits), } \\
\text { Bhumi Jambu } \\
\text { (occur in low } \\
\text { altitude regions), } \\
\text { Pika bhaksha (fruits } \\
\text { eaten by koels), } \\
\text { Bramareshta } \\
\text { (flowers liked by } \\
\text { honeybee's). }\end{array}$ \\
\hline $\begin{array}{l}\text { Rasa } \\
\text { panchaka }\end{array}$ & $\begin{array}{l}\text { Rasa-Kashaya, } \\
\text { Amla, Madhura } \\
\text { Guna- Ruksha } \\
\text { Vipaka-Katu } \\
\text { Veerya-Sheeta } \\
\text { (Ushna } \\
\text { according to } \\
\text { Raja nighantu), } \\
\text { Dosha haratva: } \\
\text { Kapha pitta hara } \\
\text { and Vata kara }\end{array}$ & $\begin{array}{l}\text { Rasa-Kashaya, } \\
\text { Madhura, Tikta } \\
\text { Guna-guru } \\
\text { Vipaka-Katu } \\
\text { Veerya- Sheeta } \\
\text { Dosha haratva- } \\
\text { Kapha pitta hara. }\end{array}$ \\
\hline Karma & $\begin{array}{l}\text { Stambhana, } \\
\text { Twak doshahara, } \\
\text { Daha } \\
\text { prasamana, } \\
\text { Deepana, } \\
\text { Pachana, Kantha } \\
\text { gharshana, Mala } \\
\text { shodhaka (bark) } \\
\text { and hrudya. }\end{array}$ & Same as Jambu \\
\hline $\begin{array}{l}\text { Safety } \\
\text { aspect }\end{array}$ & $\begin{array}{l}\text { Tambuli is } \\
\text { prepared out of } \\
\text { the tender leaves } \\
\text { in Western Ghats } \\
\text { of Karnataka } \\
\text { without any toxic } \\
\text { reactions. Jambu } \\
\text { leaf and bark } \\
\text { (70\% methanolic } \\
\text { extract) acute } \\
\text { oral toxicity } \\
\text { study was done } \\
\text { on mice. The } \\
\text { LD50 of leaf was } \\
\text { found to be } \\
3,873 \mathrm{mg} / \mathrm{kg} \text { and } \\
\text { bark was } \\
>5000 \mathrm{mg} / \mathrm{kg} \text {. } \\
(14)(15)\end{array}$ & $\begin{array}{l}\text { In Karnataka, } \\
\text { mainly in the } \\
\text { Western Ghats, } \\
\text { Kshudra Jambu } \\
\text { tender leaf is made } \\
\text { into chutney and } \\
\text { Tambuli for } \\
\text { dysentery, without } \\
\text { any toxic reactions. } \\
\text { (16)Kshudra Jambu } \\
\text { tender leaf was } \\
\text { found to exhibit no } \\
\text { toxic effects above } \\
\text { 5000mg/kg in } \\
\text { Wistar albino rats. } \\
\text { (17) }\end{array}$ \\
\hline
\end{tabular}

Youvana pidaka(Mukhadushika): (18) (19) (20) (21)

- Nidana: Excess consumption of katu, madhura, guru, snigdha, mamsa (meat), dugdha varga(milk and milk products) ahara. Vega dharana (suppressing natural urges), tarunya (teen age), vasantha-greeshma-sharat rutu and shukra dhatu mala.

- Location: Occurs in the first layer of Twacha Avabhasini, particularly on face, neck and back.

- Lakshana: A condition in which Shalmali kantaka (thorns of shalmali tree) like Pidaka appear on the face of Yuva (16-34years) which is hard in consistency, associated with pain and is filled with medha is called as Youvana pidaka.

- Dosha: Kapha, vata, rakta- initially kaphadika samsarga and in later stages it may undergo paka with pittadika samsarga.

- Dushya: Rasa, Rakta, Mamsa, Medha, shukra.

- Srotas: Rasavaha, Raktavaha, Mamasavaha, Medavaha, Swedavaha, sukravaha.

- Sroto dusti: Sangha, Atipravruthi

- Chiktsa: Siravyadha, Pralepa, Abhyanga, vamana karma, virechana karma, nasya karma and using shamana dravya which do rakta prasadhana, varnya, vrana ropana and tridosha shamana.

- Acne vulgaris (Modern correlation of Youvana pidaka): A Common skin condition wherein hair follicles develop horny plugs (comedoes) later leading to inflammation leading to tissue destruction and scaring.

\section{Materials and methods \\ Method of collection of data}

A special case Performa was prepared which included the details of history taking, physical signs and symptoms as mentioned in Ayurveda classical texts, allied science literatures and laboratory investigations related to it.

Subjects presenting with Pratyatma Lakshana (cardinal features) of Youvana Pidakaa were screened for the study at OPD of SDM college of Ayurveda and hospital, Udupi.

\section{Inclusion criteria}

30 Subjects between the age group of 16 to 34 years of either sex with cardinal features of Youvana Pidaka who have give consent for undergoing the current clinical study were included.

\section{Exclusion criteria}

Subjects with any other systemic illness undergoing treatment which might interfere with the current intervention were excluded.

\section{Investigations}

Hematological investigation like $\mathrm{Hb} \%, \mathrm{TC}$, DC, ESR, CBC was conducted if necessary.

Treatment given: (22) (23)

- Group A-Jambu mature leaf churna was given $6 \mathrm{gm}$ twice a day with hot water and lepa of Jambu mature leaf churna was told to be applied with water once a day during day time. 
- Group B- Kshudra Jambu mature leaf churna was given $6 \mathrm{gm}$ twice a day with hot water and lepa of Kshudra Jambu mature leaf churna was told to be applied with water once a day during day time.

\section{Duration of treatment: 28 days}

\section{Pathya during the treatment}

To avoid oily, spicy food, sour foods, nonvegetarian food, curd, too much sweet food, bakery food, banana, milk and milk products, Ratri jagarana (being awake at night), Diwa swapna (sleeping during day time) and alcohol consumption.

- Follow up: Every 7 days during the treatment and 30 days after the stoppage of treatment.

- Total duration of the study: 58 days

- Assessment criteria: Based on objective and subjective parameters, the assessment was done before and after treatment as follows:

\section{Itching of pidaka}

\begin{tabular}{|l|l|}
\hline No itching & 0 \\
\hline $\begin{array}{l}\text { Mild or occasional, not disturbing routine } \\
\text { activity }\end{array}$ & 1 \\
\hline $\begin{array}{l}\text { Continuous itching disturbing routine activity } \\
\text { and not disturbing sleep }\end{array}$ & 2 \\
\hline Continous itching with disturbed sleep & 3 \\
\hline
\end{tabular}

Global acne grading scale (GAGS) approved by WHO: (24)

Table 2: GAGS scoring system

\begin{tabular}{|l|c|}
\multicolumn{1}{c|}{ Location } & Factor \\
\hline Forehead & 2 \\
\hline Right cheek & 2 \\
\hline Left cheek & 2 \\
\hline Chin & 1 \\
\hline Nose & 1 \\
\hline Chest and upper back & 3 \\
\hline
\end{tabular}

No lesion $=0$, comedone $=1$, papules $=2$, pustules $=3$, and nodules $=4$.

The score for each area (local score) is calculated using the formula: Local score=factor* grade

The global score is sum of total scores and acne severity was graded using the global score.

A score of $1-18$ is considered mild; $19-30$ moderate; 31 - severe; and more than 39 , very severe

\section{Extent of lesion (in \%)}

Table 3: Extent of lesion grading Extent of lesion Involvement of face index

\begin{tabular}{|l|l|}
\hline Clean face & 0 \\
\hline $10 \%$ of face involvement & 1 \\
\hline One quarter of face involvement & 2 \\
\hline Half of face involvement & 3 \\
\hline Three quarter of face involvement & 4 \\
\hline Face fully covered by lesions & 5 \\
\hline
\end{tabular}

\section{Size of pidaka (in mm)}

A test area having maximum lesion was selected in each subject using a cardboard having $5 \mathrm{~cm}$ of inner circle. The largest lesion in that area was taken for measuring the size of pidaka in $\mathrm{mm}$ before and after treatment. (24)

\section{Number of Pidaka}

Each lesion type i.e.; comedoes, papule, pustule or nodule was counted separately and noted down before and after treatment.

\begin{tabular}{|l|l|}
\hline Hardness of pidaka & 0 \\
\hline Absence of hardness; soft lesion & 1 \\
\hline Firmness felt on palpation & 2 \\
\hline Very hard in consistency & \\
\hline Swelling of pidaka & 0 \\
\hline No swelling, no redness & 1 \\
\hline Swelling with pinkish discoloration & 2 \\
\hline Red, swollen lesion & \\
\hline Srava of pidaka & 0 \\
\hline No discharge & 1 \\
\hline Moisture on skin lesion & 2 \\
\hline Weeping from skin lesion & 3 \\
\hline Weeping from skin lesion followed by crusting & \\
\hline Healing of pidaka & 0 \\
\hline Without scar & 1 \\
\hline With minimal scar & 2 \\
\hline No healing & \\
\hline Tenderness of pidaka & 0 \\
\hline No tenderness & 1 \\
\hline Patient tells it is painfull & 2 \\
\hline Wince his/her face on touch & 3 \\
\hline Not allows touching the face & \\
\hline
\end{tabular}

\section{Statistical test applied}

Unpaired-t test and paired-t test for numeric data. Wilcoxon sign rank test and Mann Whitney test used for non-parametric data analysis.

\section{Observation and Results}

Among 30 subjects included in the study, majority of them i.e. $43.3 \%$ belonged to the age group $21-25,80.7 \%$ were female, $33.3 \%$ complained surging of Acne during the Menstural cycles, $63.3 \%$ consumed katu rasa pradhana ahara, $50 \%$ subjects had oily type of skin and $23 \%$ had combined type of skin. The observation done by subjects during the course of treatment is as in table 4. The effect of Jambu and Kshudra Jambu mature leaf within the groups after treatment is as in table 5,6 and in figures 3,4,5,6,7 and 8. The comparative effect of Jambu and Kshudra Jambu between the groups is as in table 7. The effect of two drugs after 30 days of stoppage of treatment is as in table 8 . 
Table 4: Observation by patients in two groups during treatment

Observation

Kantha garshana

Tan reduction

Loose and easy passage of stools
Group A

Present while swallowing churna

Present

Present
Group B

Present while swallowing churna

Present

present

Table 5: Effect of Jambu on different parameters of Youvana pidaka

\begin{tabular}{|c|c|c|c|c|c|c|c|}
\hline Parameter & & Mean & S.D & S.E.M & T value & Pvalue & Interpretation \\
\hline \multirow{2}{*}{$\begin{array}{l}\text { Global acne grading } \\
\text { score }\end{array}$} & Before treatment & 91.73 & \multirow[t]{2}{*}{36.769} & \multirow[t]{2}{*}{9.494} & \multirow[t]{2}{*}{5.112} & \multirow[t]{2}{*}{0.000} & \multirow[t]{2}{*}{ Highly significant } \\
\hline & After treatment & 10.26 & & & & & \\
\hline \multirow{2}{*}{$\begin{array}{l}\text { No.of. } \\
\text { comedones }\end{array}$} & Before treatment & 23.60 & \multirow[t]{2}{*}{7.825} & \multirow[t]{2}{*}{2.020} & \multirow[t]{2}{*}{6.599} & \multirow[t]{2}{*}{0.000} & \multirow[t]{2}{*}{ Highly significant } \\
\hline & After treatment & 10.26 & & & & & \\
\hline \multirow[t]{2}{*}{ No.of papules } & Before treatment & 9.867 & \multirow[t]{2}{*}{3.654} & \multirow[t]{2}{*}{0.943} & \multirow[t]{2}{*}{4.169} & \multirow[t]{2}{*}{0.001} & \multirow[t]{2}{*}{ Significant } \\
\hline & After $t$ & 5.933 & & & & & \\
\hline \multirow[t]{2}{*}{ No.of. pustules } & Before treatment & 2.8667 & \multirow[t]{2}{*}{2.404} & \multirow{2}{*}{0.620} & \multirow[t]{2}{*}{2.040} & \multirow[t]{2}{*}{0.61} & \multirow[t]{2}{*}{ Insignificant } \\
\hline & After & 16 & & & & & \\
\hline \multirow[t]{2}{*}{ No.of nodules } & Before treatment & 0.200 & \multirow[t]{2}{*}{0.560} & \multirow[t]{2}{*}{0.144} & \multirow[t]{2}{*}{1.382} & \multirow[t]{2}{*}{0.189} & \multirow[t]{2}{*}{ Insignificant } \\
\hline & Aftel & 0.0 & & & & & \\
\hline \multirow[t]{2}{*}{ Size of pidaka } & Before treatment & 2.8667 & \multirow[t]{2}{*}{1.2666} & \multirow[t]{2}{*}{0.620} & \multirow[t]{2}{*}{2.040} & \multirow[t]{2}{*}{0.61} & \multirow[t]{2}{*}{ Insignificant } \\
\hline & After treatment & 1.600 & & & & & \\
\hline \multirow[t]{2}{*}{ Extent of lesion } & Before treatment & 63.933 & \multirow[t]{2}{*}{14.633} & 3.778 & 9.793 & 0.000 & Highly significant \\
\hline & After treatment & 26.933 & & & & & \\
\hline
\end{tabular}

\section{Parameter}

Tenderness of pidaka

Hardness of pidaka

Swelling of pidaka

Srava of pidaka

Healing of pidaka

Itching of pidaka

\begin{tabular}{|c|c|}
\hline Z value & P value \\
\hline 2.449 & 0.014 \\
\hline 1.879 & 0.058 \\
\hline 2.530 & 0.011 \\
\hline 2.887 & 0.004 \\
\hline 3.051 & 0.002 \\
\hline 2.0 & 0.046 \\
\hline
\end{tabular}

\author{
Interpretation \\ Significant \\ Insignificant \\ Significant \\ Significant \\ Significant \\ Significant
}

Table 6: Effect of Kshudra Jambu on different parameters of Youvana pidaka

\begin{tabular}{|c|c|c|c|c|c|c|c|}
\hline \multirow{3}{*}{$\begin{array}{l}\text { Parameter } \\
\text { Global acne } \\
\text { grading score }\end{array}$} & & Mean & S.D & S.E.M & T value & $P$ value & Interpretation \\
\hline & Before treatment & 106.20 & \multirow{2}{*}{38.706} & \multirow{2}{*}{9.994} & \multirow{2}{*}{6.151} & \multirow{2}{*}{0.000} & \multirow{2}{*}{$\begin{array}{l}\text { Highly } \\
\text { Significant }\end{array}$} \\
\hline & After treatment & 44.73 & & & & & \\
\hline $\begin{array}{l}\text { No.of. } \\
\text { comedones }\end{array}$ & Before treatment & $\begin{array}{l}31.800 \\
14933\end{array}$ & \multirow{2}{*}{16.352} & 4.222 & 3.995 & 0.001 & Highly \\
\hline \multirow{2}{*}{ No.of papules } & $\begin{array}{l}\text { Alter treatment } \\
\text { Before treatment }\end{array}$ & $\begin{array}{l}14.933 \\
8.333\end{array}$ & & \multirow[b]{2}{*}{1.164} & \multirow[b]{2}{*}{4.350} & \multirow[b]{2}{*}{0.01} & \multirow{2}{*}{ Significant } \\
\hline & After treatment & 3.266 & 4.511 & & & & \\
\hline \multirow{2}{*}{$\begin{array}{l}\text { No.of. } \\
\text { pustules }\end{array}$} & Before treatment & 2.600 & 2.631 & 0.679 & \multirow{2}{*}{3.042} & \multirow{2}{*}{0.009} & \multirow{2}{*}{ Significant } \\
\hline & $\begin{array}{l}\text { After treatment } \\
\text { Before treatment }\end{array}$ & $\begin{array}{l}0.533 \\
0.00\end{array}$ & \multirow[b]{2}{*}{0.00} & \multirow[b]{2}{*}{0.00} & & & \\
\hline No.of nodules & After treatment & 0.00 & & & & - & Not obtained \\
\hline Size of pidaka & $\begin{array}{l}\text { Before treatment } \\
\text { After treatment }\end{array}$ & $\begin{array}{l}2.33 \\
0.93\end{array}$ & 0.986 & 0.254 & 5.501 & 0.000 & $\begin{array}{l}\text { Highly } \\
\text { significant }\end{array}$ \\
\hline Extent of lesion & $\begin{array}{l}\text { Before treatment } \\
\text { After treatment }\end{array}$ & $\begin{array}{l}42.400 \\
27.266\end{array}$ & 10.105 & 2.609 & 5.800 & 0.000 & $\begin{array}{l}\text { Highly } \\
\text { significant }\end{array}$ \\
\hline
\end{tabular}

\section{Parameter}

Tenderness of pidaka

Hardness of pidaka

Swelling of pidaka

Srava of pidaka

Healing of pidaka

Itching of pidaka

\begin{tabular}{c|} 
Z value \\
2.714 \\
2.887 \\
3.162 \\
2.271 \\
2.879 \\
2.646 \\
\hline
\end{tabular}

\section{Interpretation \\ Significant \\ Significant \\ Significant \\ Significant \\ Significant \\ Significant}

Table 7: Effect of Jambu(Group A) and Kshudra Jambu(Group B) on Youvana pidaka between the groups

\begin{tabular}{|l|c|c|c|c|c|c|c|}
\hline Parameter & Group & Difference in mean & S.D & S.E.M & T & P & Interpretation \\
\hline Global acne grading & A & 48.533 & 36.769 & 9.493 & 0.938 & 0.356 & Insignificant \\
\hline score & B & 61.466 & 38.705 & 9.993 & & & \\
\hline \multirow{2}{*}{ No.of comedones } & A & 13.333 & 7.825 & 2.02 & 0.755 & 0.457 & Insignificant \\
\cline { 2 - 9 } & B & 16.866 & 16.352 & 4.22 & & &
\end{tabular}




\begin{tabular}{|c|c|c|c|c|c|c|c|}
\hline \multirow{2}{*}{ No.of. papules } & A & 3.933 & 3.654 & 0.943 & \multirow{2}{*}{0.756} & \multirow{2}{*}{0.456} & \multirow{2}{*}{ Insignificant } \\
\hline & B & 5.066 & 4.511 & 1.164 & & & \\
\hline \multirow{2}{*}{ No.of pustules } & A & 1.266 & 2.404 & 0.620 & \multirow{2}{*}{0.869} & \multirow{2}{*}{0.392} & \multirow{2}{*}{ Insignificant } \\
\hline & B & 2.066 & 2.631 & 0.679 & & & \\
\hline \multirow{2}{*}{ No.of nodules } & A & 0.200 & 0.560 & 0.144 & \multirow{2}{*}{1.382} & \multirow{2}{*}{0.178} & \multirow{2}{*}{ Insignificant } \\
\hline & B & 0.000 & 0.000 & 0.000 & & & \\
\hline \multirow{2}{*}{ Extent of lesion } & A & 37.000 & 14.633 & 3.778 & \multirow{2}{*}{4.762} & \multirow{2}{*}{0.000} & \multirow{2}{*}{$\begin{array}{l}\text { Highly } \\
\text { significant }\end{array}$} \\
\hline & B & 15.133 & 10.105 & 2.609 & & & \\
\hline \multirow{2}{*}{ Size of pidaka } & A & 2.066 & 1.032 & 0.266 & \multirow{2}{*}{1.809} & \multirow{2}{*}{0.081} & \multirow[t]{2}{*}{ Insignificant } \\
\hline & B & 1.400 & 0.985 & 0.254 & & & \\
\hline
\end{tabular}

Parameter

Mean Rank

Tenderness of pidaka

Hardness of pidaka

Swelling of pidaka

Srava of pidaka

Healing of pidaka

Itching of pidaka A

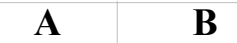

\begin{tabular}{l|l}
\hline 16.7 & 14.3 \\
\hline
\end{tabular}

17.03

16.6

14.40

16.83

17

14.3

14
14.3

Sum of Rank

A B

$250 \quad 215$

$\begin{array}{ll}250 & 215 \\ 255 & 210\end{array}$

210

$250 \quad 215$

249

14.17

216

252

255

212

210

U value

$\mathbf{Z}$ vall

94
89
96
92
90

\begin{tabular}{|l|l|l|}
\hline 94 & 0.852 & 0.394 \\
\hline 89 & 1.119 & 0.263 \\
\hline 95 & 0.825 & 0.407 \\
\hline 96 & 0.760 & 0.447 \\
\hline 92 & 0.898 & 0.369 \\
\hline 90 & 1.117 & 0.264 \\
\hline
\end{tabular}

interpretation

Table 8: Follow-up effect of Jambu and Kshudra Jambu after 30 days of stoppage of treatment.

\begin{tabular}{|c|c|c|c|}
\hline \multicolumn{3}{|c|}{ GROUP } & \multirow[b]{2}{*}{ Total } \\
\hline & Group A & Group B & \\
\hline No recurrence & $16.7 \%$ & $26.7 \%$ & $43.3 \%$ \\
\hline Recurrence with less severity & $13.3 \%$ & $13.3 \%$ & $26.7 \%$ \\
\hline Recurrence when done Nidana sevana & $20 \%$ & $10.0 \%$ & $30 \%$ \\
\hline$\%$ of Total & $50.0 \%$ & $50.0 \%$ & $100.0 \%$ \\
\hline
\end{tabular}

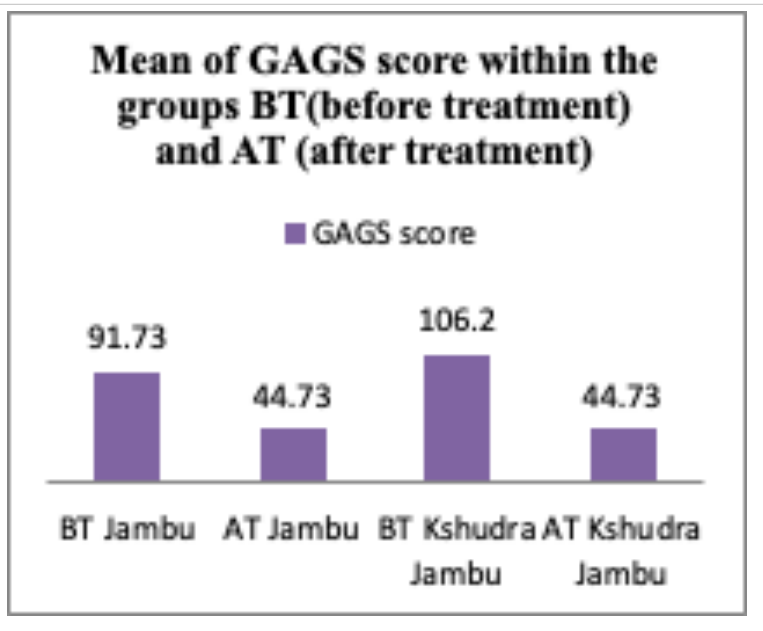

Figure 3: Mean of GAGS score

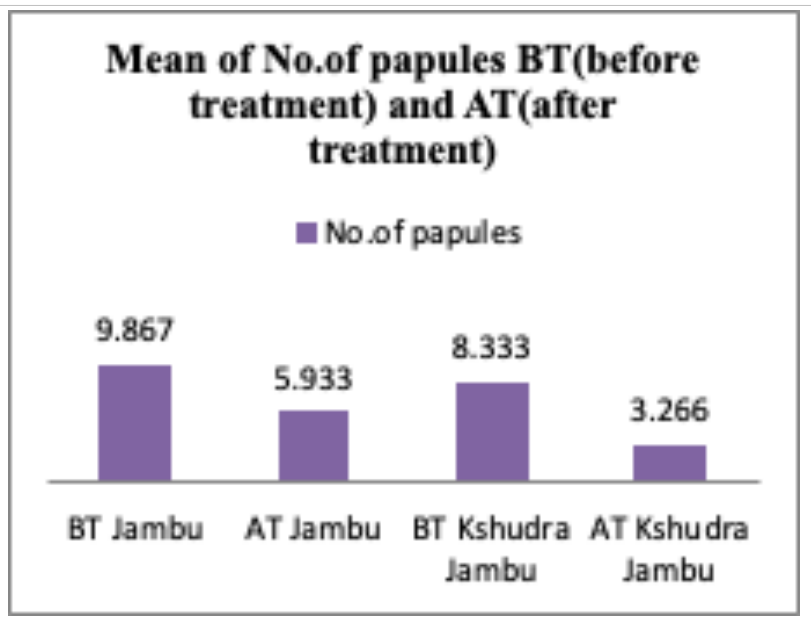

Figure 5: Mean of No. of Papules

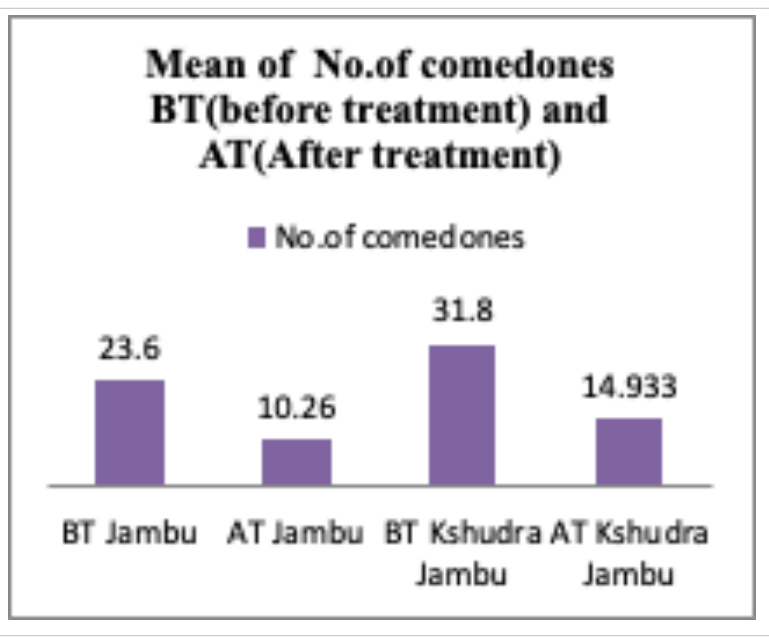

Figure 4: Mean of No. of comedones

Mean of No.of pustules

BT(before treatment) and AT

(After treatment)

No. of pustules

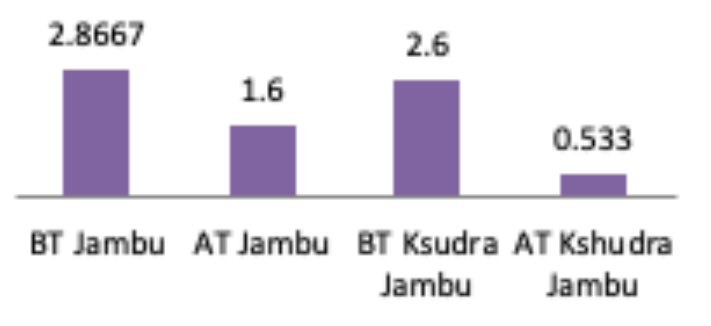

Figure 6: Mean of No. of Pustules 


\section{Mean of Extent of lesion \\ BT(Before treatment) and AT(after treatment)}

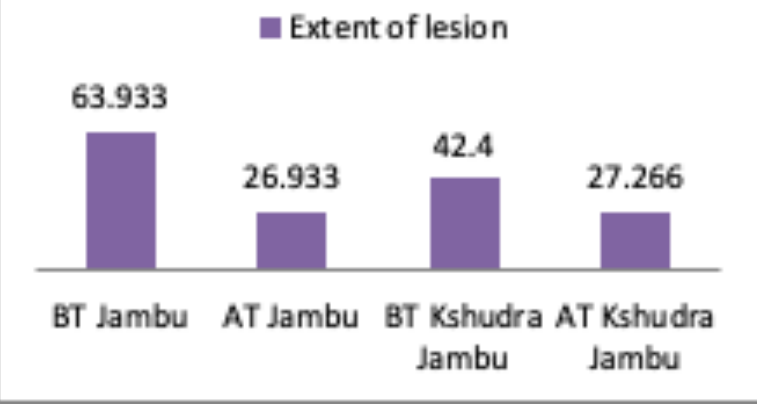

Figure 7: Mean of Extent of lesion

\section{Mean of Size of pidaka \\ BT(before treatment) and AT(after treatment)}

size of pidaka

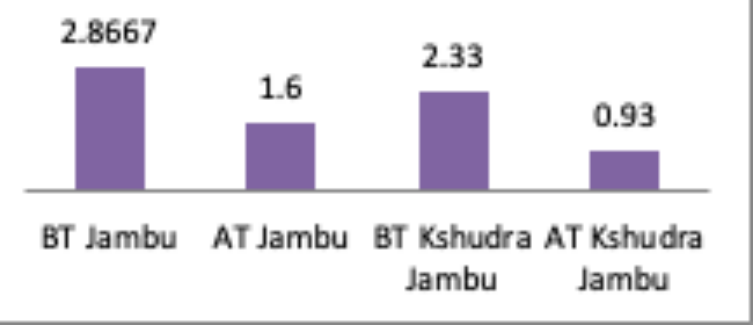

Figure 8: Mean of Size of Pidaka

\section{Discussion}

Majority of subjects belonged to the age group of 21-25 years and most of them were female, both of which cases have more hormonal variations due to swabhava of that age and monthly periods respectively. Majority of cases consumed Katu rasa pradhana ahara, which is the nidana of Youvana pidaka and which leads to Vata pitta vrudhi and Rakta dusti. Majority of subjects had oily and combined skin type; the oiliness in excess in these subjects might have blocked the sebaceous glands leading to hydrolysis of lipids by $P$. acnes bacterium, leading to inflammation and Acne.

Kanta garshana is one of the karma of both Jambu bhedha, which was appreciated by all subjects. Reduction in Tan or hyper pigmentation was observed by all subjects in both group, which implies the Varnya effect of Jambu and Kshudra Jambu.

Jambu and Kshudra Jambu are said to be Stambana in action, but all subjects taken for the study observed loose and easy passage of stools. Jambu and Kshudra Jambu Pallava (tender leaf) is mentioned by Acharya's in the treatment of Atisara and Jambu and Kshudra Jambu mature leaf is indicated in yoga's for skin manifestations like kukunaka and vyanga. When some Acharya's opined Ushna veerya of Jambu and Kshudra Jambu, it might be attributed to Jambu Bhedha mature leaf as Mrudu Sramsrana effect is required in skin manifestations like Youvna pidaka and may be due to this karma, the drug is successful in doing Samprapthi vighatana in Youvana pidaka.

Highly significant result was observed in GAGS score, number of comedones (non-inflammatory lesions of Acne which are kaphavata pradhana pidaka) and size of pidaka in both groups at the end of 28 days treatment, which shows both Jambu Bhedha reduced the overall severity of Youvana pidaka and did tridosha shamana. Group B was better that Group A but it was statistically insignificant. Papules are initial inflammatory lesion of Acne which has pitta kapha pradhana rakta dusti. Highly significant and significant improvement was observed in groups $A$ and $\mathrm{B}$ respectively in reducing number of papules and Group B $(60 \%)$ was slightly better than group A (39\%), which was statistically insignificant with $\mathrm{p}$ value 0.456 . Pustules are later inflammatory lesions of acne which have pittavata pradhana rakta dusti. Insignificant and significant results were obtained in Groups A and B respectively in reducing the number of pustules and group B $(79 \%)$ was slightly more effective than Group A (41\%), which was statistically insignificant with $\mathrm{p}$ value 0.392. Nodules are Kapha pradhana kathina (hard) pidaka in Vrana avastha of Youvana pidaka. Statistically insignificant result was found in group A in reducing the number of nodules and since the standard deviation was zero in group B as there were fewer subjects with nodules, the comparative effect in statistical terms was not possible.

Highly significant result was obtained in both groups in reducing the extent of lesion and Group A was better than Group B and the difference was statistically Highly significant with $p$ value 0.000 . Significant improvement was observed in group A and B in parameters of swelling, srava, healing and itching of pidaka and group B was slightly better than Group A except in srava of pidaka, but the difference was statistically insignificant.

$26.7 \%$ of subjects in Group B and $16.7 \%$ of subjects in Group A had no reoccurrence of Acne after 30 days of stoppage of treatment. This implies that both Jambu Bhedha leaf prevented further dosha vitiation and kept the skin healthy. $13.3 \%$ subjects each in Group $\mathrm{A}$ and $\mathrm{B}$ had reoccurrence of Acne with less severity. $20 \%$ of subjects in group A and $10 \%$ in group B had reoccurrence of Acne after Nidana sevana. This again proves that in any Roga chikitsa, Nidana parivarjana is a must.

The probable mode of action of two drugs in Yovana pidaka has been explained based on rasa panchaka, chemical constituents and pharmacological activity in Table No.8. 
Table No 8: Probable mode of action of two drugs

(25) (26) (27) (28) (29) (30) (31) (32) (33)

\begin{tabular}{|c|c|}
\hline Property/ & $\begin{array}{l}\text { Jambu and Kshudra Jambu effect in } \\
\text { Youvana Pidaka }\end{array}$ \\
\hline $\begin{array}{l}\text { Kashaya } \\
\text { rasa }\end{array}$ & $\begin{array}{l}\text { Kleda shoshana, Pidana of Pidaka } \\
\text { (containing pooya) in paaka kaala, } \\
\text { Meda Shoshana, Rakta prasadana, } \\
\text { Vrana ropana, } \\
\text { Twak prasadana and Pitta kapha } \\
\text { shamana. }\end{array}$ \\
\hline $\begin{array}{l}\text { Madhura } \\
\text { rasa }\end{array}$ & $\begin{array}{l}\text { Rasa and rakta dhatu Balya karma, } \\
\text { Vrana sandhana and Kapha pitta } \\
\text { shamana. }\end{array}$ \\
\hline Guru guna & $\begin{array}{l}\text { Vata pitta shamana, Vrana avasada } \\
\text { leading to softening of Vrana. }\end{array}$ \\
\hline $\begin{array}{l}\text { Sheeta } \\
\text { veerya }\end{array}$ & $\begin{array}{l}\text { Reduction in swedana from } \\
\text { swedavaha srotas and pitta rakta } \\
\text { shamana. }\end{array}$ \\
\hline $\begin{array}{l}\text { Rakta } \\
\text { doshahara } \\
\text { karma }\end{array}$ & $\begin{array}{l}\text { Removes doshik impurities in Rakta } \\
\text { dhatu. of Jambu bhedha does }\end{array}$ \\
\hline $\begin{array}{l}\text { Vrana } \\
\text { nashana } \\
\text { karma }\end{array}$ & $\begin{array}{l}\text { Vrana ropana during vrana stage } \\
\text { (nodule, scarring) of Youvana pidaka. }\end{array}$ \\
\hline $\begin{array}{l}\text { Chemical } \\
\text { constituents }\end{array}$ & $\begin{array}{l}\text { Alkaloids, flavonoids, sterols, } \\
\text { caumarins and } \beta \text {-caryophyllene are } \\
\text { Anti-inflammatory in action. }\end{array}$ \\
\hline $\begin{array}{l}\text { Chemical } \\
\text { constituents }\end{array}$ & $\begin{array}{l}\text { Alkaloids, flavonoids and tannins are } \\
\text { photo protective in action, which } \\
\text { might have reduced hyper } \\
\text { pigmentation in Acne. }\end{array}$ \\
\hline
\end{tabular}

bacterial

activity

Anti-oxidant Preventes oxidative stress induced

activity skin manifestations in Acne

Anti- $\quad$ Reduced the inflammation of pilo-

inflammator sebeceous glands in Acne by blocking

y activity the pro-inflammatory cytokine IL-1 in

earlier phase and epidermal growth

factor- $\alpha$ cytokine in later phase

Tikta rasa in Visha harana, Krimi harana, kusta

Kshudra hara karma, kleda meda and majja

Jambu Shoshana karma and Kapha pitta

shamana

\begin{tabular}{l|l}
$\begin{array}{l}\text { Ruksha } \\
\text { guna in } \\
\text { Jambu }\end{array}$ & $\begin{array}{l}\text { Stambana of swedavaha srotos, pitta } \\
\text { kapha shamana and reduction in Twak } \\
\text { sneha }\end{array}$ \\
\hline $\begin{array}{l}\text { Varnya } \\
\text { karma of }\end{array}$ & $\begin{array}{l}\text { Might have brought back the normal } \\
\text { color of skin in subjects }\end{array}$
\end{tabular}

Jambu

(proven by

its use in

Vyanga)

Jambu

brings back

the

normalcy in

HPO axis

\section{Conclusion}

Jambu mature leaf orally and externally was effective in bringing statistically Highly significant results in parameters like GAGS score, extent of lesion, size of pidaka, number of comedones and significant improvement in parameters like number of papules, swelling, srava and tenderness of pidaka, and insignificant improvement in parameters like number of pustules, nodules and hardness of pidaka. Kshudra $J a m b u$ mature leaf orally and externally was effective in bringing statistically Highly significant results in parameters like GAGS score, number of comedones, size of pidaka and extent of lesions, significant improvement in parameters like number of papules, hardness, tenderness, swelling, srava of pidaka and insignificant results in number of pustules.

When compared, except size of pidaka, extent of lesion and srava of pidaka, Kshudra Jambu showed slightly better action than Jambu in all parameters however the difference was not statistically significant. By virtue of Rasa panchaka, chemical constituents and through various pharmacological actions, Jambu and Kshudra Jambu brought about improvement in signs and symptoms of Youvana pidaka in the present clinical trial.

Hence in case of Youvana pidaka, Jambu and Kshudra Jambu mature leaf are equally effective in doing samprapthi vighatana.

\section{Scope for further study}

Comparative study between tender and mature leafs of Jambu and Kshudra Jambu can be studied pharmacologically and clinically. Using larger sample size, a comparative study using different parts of the same drug on a single disease can be conducted.

\section{References}

1. Department of Karnataka forest department. Sacred plants- A Book on Vratas, Gardens and the connected plants described in our Vedas and Puranas. Dharwad: J.S.S.Janata printing press; 1988.p.62-3

2. Bhavamishra. Amraadi Phala varga. In G.S.Pandey, editor. Bhavaprakasha Nighantu. Varanasi: Chaukhambha Vishwabharathi; 2013. p. 558-59.

3. Monier-williams. Maha and Kshudra. In A SanskritEnglish dictionary etymologically and philologically arranged. New Delhi: Bhrathiya grantha niketan; 2013. p. 330,794.

4. S Ravikrishna. Syzygium caryophyllatum. In Ethno-Medico Botanical survey on Wild edible fruits of Udupi Taluq. Udupi: RGUHS; 2011. p. 96-97.

5. Subramanya K. Syzygium cumini, Syzygium caryophyllatum. In Exploration and Elucidation of Traditional medicinal plants of Erstwhile Tulunadu and surrounding area of Kerala and Karnataka. Kerala: Kannur University; 2012. p. 970-72.

6. Jain SK. Syzygium cumini, Syzygium caryophyllatum. In Dictionary of Indian Folk 
Medicine and Ethnobotany. New Delhi: Deep publications; 1991. p. 311.

7. Richard motley RM. Acne, rosaceae and similar disorders. In Common Skin diseases. 18th ed. UK: CRC press; 2011. p. 384.

8. Madhavakara. Kshudra roga. In Madhava Nidana. Repritn edition ed. Varanasi: Chaukhambha; 2009. p. 181.

9. http://envis.frlht.org/plantdetails/ f98e7dfea5d923f2cd106d1c6da3b936/44bbcff8f96d 2a8273fd4d67e7445570 \# dated 1-1-2020 time:14.00 IST

10. 10 G.Bapalal. Jambvaadi varga. In Nighantu Adarsha. Varanasi: Chaukhamba bharathi academy; 2007. p. 581-86.

11. Kaiyadeva. Aushadhi Varga. In P.V.Sharma, editor. Kaiyadeva Nighantu. Varanasi: Chaukhambha orientalia; 1676. p. 65-66.

12. Madanapala. Phalaadi Varga. In J.L.N.Shastry, editor. Illustrated Madanapala Nighantu. Varanasi: Chaukhamba Sanskrit series; 2010.

13. Shankara. Jambu. In Shankara Nighantu. Varaanasi: Chaukhambha Vidyabhavan; 2002. p. 103-4.

14. Akhtar M. Nutritional, Therapeautic and Food applications of Jamun (Syzyghium cumini). Canadian Journal of Food sciences and Technology. 2016 August; 1(1): p. 1-8.

15. Teresa May B et al. Syzygium cumini (1.) Skeels: a review of its phytochemical constituents, toxicity studies and traditional and pharmacological uses. International journal of Applied Pharmaceutical and Biological Research. 2017; 2(6): p. 15-23.

16. Agarwal $\mathrm{P}$ et al. Polyherbal anti acne gel containing Mangifera indica and Syzygium cumini seeds: Bioassay guided activity against Propionobacterium acne. Biointerface research in applied chemistry. 2019; 9.

17. Parvathy.S. Pharamacognostic and experimental evaluationm of tender leaf of BhumijambuSyzygium caryophyllatum (L.) Alston in Ulcerative colitis. Journal of Ayurveda medical sciences. 2018; 3(1): p. 294-295.

18. Atreya, Charaka, Dridhabala. Charaka samhitha with Ayurveda dipika commentary of Chakrapani datta Y.T.Acharya , editor. Varanasi: Chaukhambha surabharathi; 2011.

19. S.Gopakumar. Acne vulgaris. In SPARSHAM (Clinical presentations on skin diseases). Kerala: Time Offset printing press; 2015. p. 99-100.

20. Sushrutha. Sushrutha samhitha with Nibandhasangraha commentary of Dalhana and Nyayachandrika commentary of Gayadasa. reprint ed. N.R.Kavyatirtha YTA, editor. New Delhi: Chaukhambha publications; reprint 2010.

21. Sharma M. A Conceptual study of ayurvedic management of mukhadushika w.s.r to acne vulgaris: a review. International journal of Ayurveda and pharma research. 2016; 4(9): p. 78-82.

22. Sharangadhara. Phanta kalpana, Lepa kalpana, churna kalpana, Kshudra roga. In Shastri p, editor. Sharangadhara samhitha with the dipika commentary of Adhamalla and gudartha dipika of kashirama. Bombay: Nirayana sagar press; 1931. p. 870.

23. Angadi R. Lepa Kalpana. In A Textbook of Bhasishjya kalpana vijyana (pharmaceutical science). New Delhi: Chaukhambha Surabhrati prakashana; 2020. p. 559.

24. B.Adithyan et al. Scoring systems in acne vulgaris. Indian J Dermatol Venereol Leprol. 2009 december; 75: p. 323-6.

25. Vagbhata. Astanga Hrudaya Samhitha with Arunadatta and hemadri commentary. reprint edition ed. Paradakara HIGHLY SIGNIFICANTS, editor. New Delhi: Chaukhambha Publications;2010.p.892

26. Mayuri A et al. Role of Syzygium cumini (jamun) in cosmetic. IJSDR. 2019; 4(6): p. 193-201.

27. Khare CP. Syzygium species. In Indian medicinal plants- An Illustrated Dictionary. First reprint ed. New Delhi: Springer(India) Private Limited; 2007. p. 637-37.

28. Anil Kumar et al. Pharmacognostic Evaluation of Eugenia jambolana (Linn.) Leaves. JPBMS. 2011; 11(11): p. 1-2.

29. Annadurai $G$ et al. Antimocrobial, antioxidant, anticancer activities of Syzygium caryophyllatum (L.) Alston. International journal of greeen pharmacy. 2012; 6(4): p. 285-288.

30. Deepthi K et al. Recent advances in pharmacological potential of Syzygium cumini: A review. Pelagia research library. 2016; 7(3): p. 1-12.

31. Emil.A.Tangetti. Role of Inflammation in the pathology of Acne. J Clin Aesthet Dermatol. 2013 september; 6(9): p. 27-35.

32. Heendeniya SNs et al. In vitro investigation of antyi-inflammatory activity and evaluation of phytochemical profile of Syzygium caryophylloatum. Journal pf pharmacology and phytochemistry. 2018; 7(1): p. 1759-1763.

33. Benevides R et al. Syzygium cumini (L.) Skeels improves metabolic and ovarian parameters in female obese rats with malfunctioning hypothalamus-pituitary-gonadal axis.. J Ovarian Res. 2019; 12(13). 